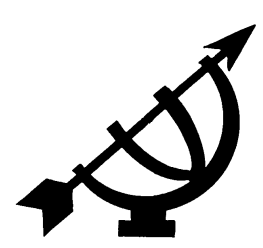

\title{
"Om te kan asemhaal": transformerende mimesis as voorwaarde vir betrokkenheid in die poësie van Antjie Krog
}

\author{
C. Kostopoulos \\ Departement Filosofie \\ Universiteit van Johannesburg \\ E-pos: candess.kostopoulos@gmail.com
}

\begin{abstract}
"In order to breathe": transformative mimesis as a condition for commitment in the poetry of Antjie Krog

Committed writing makes salient a type of relationship between text, reality and reader which presupposes mimesis. Mimesis is, however, a seemingly outdated concept in literary aesthetics. Therefore, it is necessary to rehabilitate mimesis conceptually in order to account for actual literary commitment. This rehabilitation can be done via Paul Ricoeur's theory of a threefold mimesis, also known as mimetic arc. The mimetic arc allows a view of mimesis that privileges neither aesthetic autonomy nor aesthetic heteronomy. Thereby the power of art to influence society is preserved without compromising its unique aesthetic goals and characteristics. The threefold mimetic process consequently points towards a transformative mimesis, which acts as the condition for the possibility of literary commitment itself. The principles of transformative mimesis are present in the poetry of Antjie Krog in a salient and enlightening way, making her poetry exemplary committed art.
\end{abstract}

\section{Opsomming}

"Om te kan asemhaal": transformerende mimesis as voorwaarde vir betrokkenheid in die poësie van Antjle Krog

Betrokke skryfwerk benadruk 'n tipe verhouding tussen die teks, die werklikheid en die leser en dit veronderstel mimesis. Mimesis is egter 'n oënskynlik uitgediende konsep in die literêre estetika. Daarom is dit noodsaaklik om mimesis konseptueel te rehabiliteer ten einde wesenlike literêre betrokkenheid te kan verreken. Sodanige rehabilitasie kan gedoen word via Paul 
Ricoeur se teorie van drievoudige mimesis, ook bekend as die mimetiese boog. Die mimetiese boog laat 'n siening van mimesis toe wat nóg estetiese outonomie, nóg estetiese heteronomie privilegeer. Daardeur word die invloedsfeer van kuns in die samelewing behou, sonder dat kuns se eiesoortige doelwitte en karaktertrekke prysgegee word. Die drievoudige mimetiese proses dui gevolglik op 'n transformerende mimesis wat as die moontlikheidsvoorwaarde van literêre betrokkenheid self dien. Die beginsels van transformerende mimesis is op 'n duidelike en insiggewende wyse teenwoordig in die poësie van Antjie Krog. Haar poësie kan derhalwe as eksemplariese-betrokke kuns beskou word.

\section{Inleiding}

Wat maak die verskynsel van literêre betrokkenheid moontlik?1 In hierdie artikel voer ek aan dat 'n tipe mimetiese verhouding tussen die literêre teks en die werklikhede wat dit omring, 'n voorwaarde 2 vir betrokkenheid is. Ek argumenteer verder dat Antjie Krog se poësie in hierdie verband eksemplaries is. Die konsep mimesis is egter oënskynlik uitgedien in die literêre estetika. Mimesis word eerstens as 'n verouderde begrip beskou omdat dit bykans uitsluitlik met die antieke estetika van onderskeidelik Plato en Aristoteles vereenselwig word. 3 Voorts is representasie sodanig geproblematiseer deur die poststrukturalisme se kritiek op betekenis en verwysing, dat mimesis op 'n selfs meer fundamentele, metateoretiese vlak onder verdenking is. 4

1 In hierdie artikel aanvaar ek dat betrokkenheid werklik is en word argumente vir die teendeel nie bespreek nie.

$2 \quad$ Voorwaarde word hier in die Kantiaanse sin van die woord gebruik en moet derhalwe nie gelykgestel word aan iets voorskrifteliks nie.

3 Bykans alle basiese geskiedskrywings en/of oorsigte van estetika of literêre teorie is skuldig hieraan. Alhoewel dit 'n gesofistikeerde uiteensetting is, is iets soos M.H. Abrams se The mirror and the lamp (1953) 'n goeie voorbeeld van die bykans onnadenkende gelykstelling van mimesis aan veral Plato se kunsteorie. Twee resente, maar invloedryke voorbeelde waarin sodanige gelykstelling plaasvind, is Arthur Danto se After the end of art (1997) en Jacques Rancière se The politics of aesthetics (2006).

4 Die werk van Jacques Derrida kan steeds hier as paradigmaties beskou word, ook omdat hy spesifiek infokus op en krities staan teenoor mimesis. Vergelyk veral sy La Dissémination (Derrida, 1972). Alhoewel die term poststrukturalisme nie in hierdie geval gebruik kan word nie, kan 'n mens in die analitiese tradisie ook die werk van Nelson Goodman uitsonder as 'n kontemporêre estetika wat radikaal antimimeties is. Vergelyk veral sy Languages of art (Goodman, 1968). 
Stephan Halliwell som die "agterdog" waarmee mimesis tans bejeën word goed op wanneer hy skryf dat dit vandag beskou word as "little more than a broken column surviving from a long-dilapidated classical edifice, a sadly obsolete relic of former times" (Halliwell, 2002: 344). In die besonder kom kritiek teen mimesis (onder die vaandel van kritiek teen representasie) in twee gedaantes voor, naamlik ideologies en epistemologies (vgl. Halliwell, 2002). Epistemologies gesproke word mimesis (veral wanneer dit gelykgestel word aan weerspieëling) gewoonlik sonder meer aan 'n naïewe korrespondensieteorie van die waarheid verbind. Die idee dat die mens onbemiddelde en passiewe toegang tot die werklikheid het, is reeds deur Kant in twyfel getrek en (oënskynlik finaal) deur die poststrukturalisme afgebreek. Wie die naïewe korrespondensieteorie van die waarheid voorhou, maak egter (volgens denkers wat krities daarteenoor ingestel is) nie nét 'n epistemologiese "fout" nie, maar 'n aandrang op onbemiddelde toegang tot die werklikheid vorm die basis van talle magsvergrype en euwels. ${ }^{5}$ Representasie is om hierdie rede nie net 'n epistemologiese term nie, maar ook 'n begrip met bepaalde ideologiese konnotasies.

Vir die estetika in die besonder beteken die (dikwels vervlegte) epistemologiese en ideologiese kritiek op mimesis qua representasie, dat kuns nie werklik kontak met die werklikheid maak nie, maar eerder 'n eie werklikheid skep of, meer spesifiek, 'n eie tipe werklikheid is. In hierdie opsig is dit moontlik nie toevallig dat Alexander Baumgarten estetika en heterokosmos (heterocosmica) as terme albei op dieselfde tydstip (die Verligtingsera) tot ons woordeskat bygedra het nie (vgl. Halliwell, 2002:4). Sedertdien is die verhouding tussen estetiese outonomie en estetiese heteronomie een van die brandpunte in die estetika, veral wanneer dit by betrokke kuns kom. 'n Bepaalde tipe verhouding moet trouens tussen teks en werklikheid bestaan ten einde literêre betrokkenheid wesenlik te maak. Die werklikheid moet op die teks en die teks weer op die leser(s) kan inspeel op 'n wyse wat radikaal is, deurdat 'n verandering (hetsy in houding, denke of optrede) in die leser(s) teweeggebring kan/moet word. Die verskynsel van literêre betrokkenheid beklemtoon, na my mening, juis hierom die metateoretiese vooronderstellings van baie

5 Die bekendste resente voorbeeld van argumente in hierdie trant is Phillippe Lacoue-Labarthe se poststrukturele kritiek op Heidegger se Nazisme as iets wat moontlik gemaak is deur die "mimetiese" vooronderstellings van sy siening van kuns en waarheid (vgl. Lacoue-Labarthe en Jean-Luc Nancy se artikel "The Nazi myth" [Lacoue-Labarthe \& Nancy, 1989] vir 'n bondige uiteensetting van hierdie argument). 
estetikas wat negatief teenoor representasie ingestel is. Die uiterste manifestasies van sodanige estetikas kan immers nie anders as om 'n breuk tussen teks en werklikheid te veronderstel wat die literêre kunswerk se maatskaplik-politieke relevansie drasties inkort nie. 6 In die lig hiervan argumenteer ek dat 'n konseptueel-gerehabiliteerde of "herwinde" begrip van mimesis nodig is om die teks-werklikheidverhouding wat betrokkenheid moontlik maak, te kan verreken. Die doel van hierdie artikel is dus nie om 'n diepgaande literêre analise van bepaalde tekste (in hierdie geval die poësie van Antjie Krog) te maak, óf om pertinent op spesifieke debatte in die literêre teorie kommentaar te lewer nie. Die uiteindelike oogmerk bly 'n filosofiese besinning oor die voorwaarde(s) van betrokkenheid. Ek bespreek en verdedig eerstens 'n filosofiese teorie van mimesis. Dit het, myns insiens, die potensiaal om betrokkenheid die beste te kan verreken. Daarna lig ek die wyses uit waarop Antjie Krog se poësie sodanige teorie "verhelder".

\section{Transformerende mimesis}

Alhoewel dit redelik algemeen aanvaar word dat ons in 'n postmimetiese era leef, is daar 'n beduidende aantal denkers (bv. Adorno, Murdoch, Gadamer en Walton) wat mimesis steeds ernstig opneem (Halliwell, 2002:345). Die Franse filosoof Paul Ricoeur (1913-2005) bedien ons van een van die vrugbaarste mimesisteorieë. Sy ontwikkelde teorie van mimesis kom die eerste keer voor in Temps et récit (Time and narrative in Engels, 1990a \& 1990b), maar elemente van sy teorie is reeds vroeg al in sy werk teenwoordig. Wat Ricoeur se werk oor die onderwerp uitsonderlik maak, is dat hy 'n besonder genuanseerde begrip van mimesis het. Soos Derrida is hy krities ingestel teenoor sekere modernistiese aannames met betrekking tot die verhouding tussen taal, waarheid en werklikheid. Anders as Derrida, probeer hy egter om die idee van representasie, ten spyte van die heersende "skeptisisme", te "stabiliseer" (Halliwell, 2002:345). Voordat die voordele van sy mimesisteorie egter bespreek kan word, is dit eers nodig om dit in meer detail uiteen te sit.

6 Die beperkte formaat van 'n artikel laat my nie toe om verder op hierdie argument in te gaan nie. Ek aanvaar dat dit vir die leser duidelik genoeg is. Die geïnteresseerde leser kan egter gerus die volgende bronne raadpleeg: A.M. de Lange se opstel Writer, reader and representation, or; The theory and practice of commitment (1995); Terry Eagleton se Marxism and literary criticism (1976); en Theodor Adorno se bekende opstel "Commitment" (1977). 


\subsection{Ricoeur se teorie van drievoudige mimesis}

Ricoeur poog om die idee van representasie te stabiliseer. Hy ontwikkel egter nie self 'n estetika nie. Indien 'n mens Ricoeur se oeuvre fynkam vir 'n teorie wat die probleem van betrokkenheid kan verhelder, vind 'n mens die mees eksplisiete verwysings daarna in sy werk oor mimesis. Ricoeur se teorie van mimesis is in deel 1.3 van die eerste volume van Temps et récit (Ricoeur, 1990a:52-87) te vind. Hier voeg hy die onafhanklike "inleidings" van onderskeidelik Augustinus oor tyd, en Aristoteles oor narratief, vir die eerste keer saam met die oogmerk om die bestaan van 'n intieme of "transkultureel noodsaaklike" korrelasie tussen hierdie twee oënskynlik uiteenlopende besinnings te bewys (Ricoeur, 1990a:52). Die riglyn wat hy volg om hierdie korrelasie te bevestig, vind hy "die eerste keer" in Aristoteles se bespreking van mimesis in die Poetika. Ricoeur se rekonstruksie van mimesis is egter 'n hoogs oorspronklike uitbreiding van Aristoteles se idees, een waarin hy spesifiek 'n teorie van drievoudige mimesis ontwikkel. Hy het hierdie teorie spesifiek ontwikkel met die oog daarop om die oënskynlike kloof tussen tyd en narratief te probeer bemiddel. Vir ons doeleindes is dit egter slegs nodig om sy teorie van drievoudige mimesis as sodanig te behandel.

Ricoeur (1990a:53) onderskei, op 'n speelse, dog ernstige wyse, drie "oomblikke van mimesis": mimesis ${ }_{1}$, mimesis ${ }_{2}$, en mimesis m. $_{3}$. Dit is slegs mimesis $_{2}$ wat geïdentifiseer kan word met 'n literêre kunswerk as sodanig. Mimesis ${ }_{1}$ en mimesis m $_{3}$ verteenwoordig onderskeidelik die mimetiese aktiwiteite wat vóór en ná 'n werk plaasvind. Eersgenoemde bestaan uit 'n voorverstaan van die werklikheid, laasgenoemde uit die resepsie van die werk en die dienooreenkomstige effek wat dit op die resepteerder het. Mimesis ${ }_{1}$ veronderstel in die besonder 'n drievoudige bevoegdheid. Eerstens is 'n voorlopige bevoegdheid nodig, naamlik die vermoë om elemente in die werklikheid in die algemeen en deur middel van die strukturele wesenstrekke daarvan te kan identifiseer (Ricoeur, 1990a:54). Hiervoor is 'n praktiese begrip nodig wat die bemeestering van 'n konseptuele netwerk behels. Dit moet byvoorbeeld die domein van menslike handeling struktureel kan onderskei van die domein van blote fisiese beweging (Ricoeur, 1990a:55).

Hiernaas is 'n tweede bevoegdheid nodig, naamlik die vermoë om die simboliese trekke van die werklikheid, wat Ricoeur (1990a:54) symbolic mediations noem, te kan identifiseer. Ricoeur gaan hier van die veronderstelling uit dat menslike handeling in 'n narratief omgesit kan word slegs as gevolg van die feit dat handelinge altyd reeds geartikuleer word deur tekens, reëls en norme (Ricoeur, 
1990a:57). Ricoeur kies om die begrip simbool in 'n sogenaamde middle sense te gebruik, met ander woorde halfpad tussen eenvoudige notasie en dubbel-betekenis uitdrukking7. Simboliese mediasie dui dus spesifiek op die gestruktureerde aard van 'n simboliese sisteem en daarom verskaf dit 'n initial readability aan die waargenome werklikheid (Ricoeur, 1990a:58). In hierdie konteks voer die mediasie van die simboliese strukture eie aan 'n kultuur die idee van 'n reël in, maar dan in die breër sin van 'n norm. Die uiteindelike literêre werk (mimesis ${ }_{2}$ ) behels dus nooit 'n absolute nuutskepping of 'n skep ex nihilo nie; dit "vermeerder egter die werklikheid". Die werk dra dus iets betekenisvols by tot die simboliese mediasie(s) wat dit voorafgaan.

Die derde bevoegdheid van voorverstaan is die vermoë om die temporele dimensie van die werklikheid, en spesifiek van handeling, te herken (Ricoeur, 1990a:59). Sodanige bevoegdheid is meer streng van toepassing op narratief as sodanig, maar ander kunswerke met 'n narratiewe element sou ook hierdie vermoë veronderstel. 8 Hoe dit ook al sy, die betekenisrykheid van mimesis ${ }_{1}$ is duidelik sigbaar in die drievoudige bevoegdheid wat dit veronderstel. Om iets (in die spesifieke geval van Temps et récit, menslike handeling) te kan weergee, is dit eerstens belangrik om vooraf te verstaan wat handeling werklik is. Dit is juis op grond van hierdie voorverstaan dat literêre mimesis gekonstrueer word. "Literature would be incomprehensible," argumenteer Ricoeur (1990a:64) met reg, "if it did not give a configuration to what was already a figure in human action". Die literêre werk self is dus net 'n bepaalde oomblik binne 'n meer omvattende mimetiese boog.

Mimesis $_{2}$ - die werk as sodanig - is gevolglik 'n spesiale tipe of kreatiewe nabootsing, deur middel van bepaalde menslike vermoëns, van wat werklik is. In die geval van narratiewe fiksie (soos dit bespreek word in Temps et récit) is mimesis ${ }_{2}$ dus die kreatiewe nabootsing van handeling deur middel van die vermoë om verhale te konstrueer, of die oomblik waarop die "kingdom of the as if" deur emplotment oopgemaak word (Ricoeur, 1990a:64). Mimesis ${ }_{2}$ is

7 Ricoeur se siening van die simbool is dus nader aan Ernst Cassirer en Clifford Geertz se idee van die simbool as 'n funksie van kulturele mediasie.

8 Heidegger se eksistensiële analise van intra-temporaliteit of being-in-time (Innerzeitigkeit) bied op hierdie punt van sy eie analise vir Ricoeur (1990a:61) die beste karakterisering van die temporaliteit van handeling. 
vervolgens by uitstek die oomblik van mediasie 9 waarin daar 'n spesiale tipe samevoeging plaasvind tussen die werklikheid en die teks. Sodanige samevoeging is volgens Ricoeur (1990a:66) nóú verwant aan Kant se siening aangaande die wyses waarop die menslike oordeelsvermoë funksioneer. In die geval van fiksie behels die konfigurerende handeling van narratief nie soseer die bind van 'n subjek aan 'n predikaat nie, maar eerder dat 'n intuïtiewe menigvuldigheid onder die regulasie of ordeskeppende logika van 'n konsep saamgebring word. Die verbintenis wat Ricoeur tussen mimesis $_{2}$ en oordeelsvermoë trek, blyk voorts toenemend hegter te word soos daar wegbeweeg word van die bepalende oordeelsvermoë van die Kritik der reine Vernunft, na die reflekterende oordeelsvermoë van die Kritik der Urteilskraft (Ricoeur, 1990a:66). Die verbintenis tussen mimesis ${ }_{2}$ en reflekterende oordeelsvermoë impliseer dat skepping (poiēsis) baie meer behels as om net heterogene elemente uit die werklikheid saam te voeg in 'n tipe literêre produk (of in die konteks van Temps et récit: om die paradoks van temporaliteit te weerspieël deur middel van narratief). Mimesis ${ }_{2}$ bewerkstellig "... a solution that is the poetic act itself" (Ricoeur, 1990a:66). Daar is dus sekere dinge wat nét deur middel van die skeppende arbeid van kuns vir 'n mens verstaanbaar is. Estetiese outonomie is in Ricoeur se mimesisteorie nie ten koste van heteronomie nie. Trouens, mimesis ${ }_{2}$ is onlosmaaklik verbind aan sowel mimesis $_{1}$ as mimesis $_{3}$.

Ricoeur se klem op die reflekterende oordeelsvermoë lei ook 'n belangrike bespreking van die rol van die produktiewe verbeelding (in die Kantiaanse sin van die woord) in. Op dieselfde wyse as wat grasping together van die konfigurerende handeling vergelyk kan word met Kantiaanse oordeelsvermoë, is die produksie van die konfigurerende handeling vergelykbaar met sy (Ricoeur se) idee van die produktiewe verbeelding (Einbildungskraft). Volgens Ricoeur (1990a:68) kan 'n mens teen die agtergrond van hierdie vergelyking praat van 'n tipe literêre "skematisme". Hierdie skematisme is gekonstitueer binne 'n literêre geskiedenis wat al die trekke van 'n tradisie vertoon, spesifiek verstaan as 'n lewendige oordrag wat

9 In die geval van fiksie is mimesis 2 spesifiek 'n drievoudige mediasie. Eerstens medieer die plot tussen individuele gebeurtenisse en insidente en die verhaal as geheel; tweedens voeg emplotment 'n reeks heterogene faktore saam soos agente, doelwitte, interaksies, omstandighede en boonop vreesaanjaende, bejammerenswaardige, skielike en skokkende insidente; derdens sintetiseer plot die heterogene spesifiek deur middel van die eie temporele eienskappe daarvan (Ricoeur, 1990a:65-66). 
gekonstitueer word deur die "dialektiese tussenspel van innovasie en sedimentasie", en nié as die "inert transmission of some already dead deposit of material" nie (Ricoeur, 1990a:68). Literêre skemas sedimenteer gevolglik en gee sodoende aanleiding tot die totstandkoming van literêre tradisies. Elke nuwe literêre werk impliseer dan 'n afwyking met betrekking tot hierdie tradisies. Innovasie handhaaf dus strykdeur 'n verhouding, wat soms vol konflik kan wees, met sedimentasie en gee self weer aanleiding tot nuwe tradisies. Weereens het ons dus hier te doen met 'n siening van kuns wat die literêre werk as selfstandig, maar nie as onafhanklik beskou nie. Dit is egter eers wanneer ' $n$ mens die laaste oomblik van mimesis begryp dat jy die volle implikasies van hierdie siening kan peil.

Mimesis $_{3}$ markeer die punt waarop die wêreld van die teks die wêreld van die leser of aanhoorder kruis (Ricoeur, 1990a:71). Hierdie dinamika vind veral uitdrukking in die oorgang vanaf mimesis ${ }_{2}$ na mimesis $_{3}$ - 'n oorgang wat teweeggebring word deur die leeshandeling. Die leeshandeling word verbind aan die teks se vermoë om dinge (bv. ervarings en emosies) te modelleer, aangesien dit die skeppende konfigurasie weer opneem en verwesenlik. Skematisering en tradisie getuig verder van die wyse waarop die leeshandeling die vooroordeel afbreek wat 'n binne- en buitekant van 'n teks postuleer, omdat die idee van 'n strukturerende aktiwiteit enige sodanige opposisie te bowe gaan (Ricoeur, 1990a:76). Skematisering en tradisionaliteit is dus oorspronklik reeds kategorieë van interaksie tussen die werking (operativité) van skryf en van lees.

On the one hand, the received paradigms structure the readers' expectations and aid them in recognizing the formal rule, the genre, or the type exemplified by the narrated story [...]. On the other hand, it is the act of reading that accompanies the narrative's configuration and actualizes its capacity to be followed. (Ricoeur, 1990a:76.)

Om 'n literêre werk te volg, is dus om die werk te aktualiseer of te verwerklik deur dit te lees (hierdie begrip kan ook aandagtige luister insluit). Dit verduidelik waarom 'n leser 'n werk voltooi (klaar lees) en somtyds selfs, in ekstreme gevalle soos Joyce se Ulysses, ook die las van skeppende arbeid moet dra (Ricoeur, 1990a:77). Uiteindelik kan mimesis ${ }_{2}$ dus slegs beskryf word as 'n akte van oordeel en produktiewe verbeelding in soverre sodanige akte bestaan uit die gesamentlike werk van tekste en leser.

Die voltooiing van 'n teorie van skryf met 'n teorie van lees, put egter nie die ganse betekenisomskrywing van mimesis $_{3}$ uit nie. "An aes- 
thetic of reception", soos Ricoeur (1990a:77) dit stel, "cannot take up the problem of communication without also taking up that of reference". Hierdie veronderstelling, wat Ricoeur (1990a:78) die "ontologiese voorveronderstelling van verwysing" noem, moet ook gekoördineer word met die leeshandeling: "An ability to communicate and a capacity to refer must be simultaneously posited" (Ricoeur, 1990a:78). Alle verwysings is gevolglik co-reference of dialogiese verwysing, met die gevolg dat 'n hele verskeidenheid literêre "gevalle" moontlik is en dit nie nodig is om te kies tussen 'n resepsieestetika en 'n ontologie van die kunswerk nie (Ricoeur, 1990a:7879). Literêre werke besit uiteindelik die vermoë om deur middel van 'n tweede-ordeverwysing of iconic augmentation 'n mens se verhouding tot die werklikheid te intensiveer deur die wêreld opnuut te beskryf of te herfigureer. Die verbeelding funksioneer in hierdie instansie nie as 'n dupliseerder van die werklikheid nie, maar eerder as 'n kreatiewe vertolker daarvan.

The more imagination deviates from that which is called reality in ordinary language and vision, the more it approaches the heart of reality which is no longer the world of manipulable objects, but the world into which we have been thrown by birth and within which we try to orient ourselves by projecting our innermost possibilities upon it, in order that we dwell there, in the strongest sense of that word. (Ricoeur, 1991:133.)

Letterkunde stel 'n mens in staat om via die drievoudige mimetiese boog die werklikheid op 'n alternatiewe, dikwels meer insiggewende wyse waar te neem, deurdat dit die (moontlikhede in en van die) werklikheid op 'n produktiewe en arbeidsame wyse vermeerder, uitbrei of verryk. 'n Dubbele vooroordeel word volgens Ricoeur (1991: 133) hierdeur verplaas, naamlik die vooroordeel van algemene taalgebruik en die populêre siening van die wetenskap wat albei die idee bevorder van die wetenskap as 'n objektiewe weergawe van die werklikheid, en kuns as 'n subjektiewe bedryf wat sonder enige waarheidsaansprake is. Die rol van die hermeneutiek is dus om, in 'n spiraalagtige beweging van toenemende begrip, die mimetiese boog te herkonstrueer, sodat die spesiale tipe waarheidsaansprake van kuns geaktualiseer kan word (Ricoeur, 1990a:53).

\subsection{Drievoudige mimesis as transformerende mimesis}

Ricoeur se genuanseerde beskouing van mimesis as 'n stel interafhanklike prosesse maak 'n beskouing moontlik wat die digotomie tussen kuns-as-subjektiwiteit en (natuur)wetenskap-as-objektiwiteit oorstyg. Hierdie siening laat ons toe om die literêrheid van die 
letterkunde as iets te beskou wat juis die spanning tussen outonomie-heteronomie veronderstel. In Temps et récit argumenteer Ricoeur (1990a:53) juis dat die konstruksie of konfigurasie, met ander woorde die maak van narratiewe diskoers (mimesis ${ }_{2}$ ), "the literariness of the work of literature" verteenwoordig. Sy hipotese is dat aan die literêrheid van narratiewe fiksie juis 'n betekenis toegeken kan word as gevolg van die tussenposisie wat dit beklee met betrekking tot die voorverstaan van die konkrete werklikheid (mimesis ${ }_{1}$ ) en die verhoogde begrip van die werklikheid wat deur die leser(s) ingevul word (mimesis ( $_{3}$. Op hierdie punt is dit raadsaam om Ricoeur self aan die woord te stel:

[M]imesis ${ }_{2}$ draws its intelligibility from its faculty of mediation, which is to conduct us from the one side of the text to the other, transfiguring the one side into the other through its power of configuration [...] It is the task of hermeneutics ... to reconstruct the set of operations by which a work lifts itself above the opaque depths of living, acting, and suffering, to be given by an author to readers who receive it and thereby change their acting. For a semiotic theory, the only operative concept is that of the literary text. Hermeneutics, however, is concerned with reconstructing the entire arc of operations by which practical experience provides itself with works, authors, and readers. (Ricoeur, 1990a:53; kursivering - CK.)

Die literêrheid van letterkunde word dus saamgestel uit die vermoë van letterkunde om tussen prekonfigurasie of voorverstaan (mimesis $_{1}$ ), en herkonfigurasie of ' $n$ verhoogde verstaan (mimesis ${ }_{3}$ ) te medieer. Anders gestel: die outonomie van die literêre kunswerk is 'n tipe outonomie wat voorafgegaan moet word deur 'n bepaalde voorverstaan van die werklikheid en voltooi moet word deur resepsie.

Ricoeur se denke vertoon op hierdie punt 'n geweldige filosofiese wydheid wat moeilik geparafraseer kan word. Indien Temps et récit egter deur die lens van die sentrale probleem gelees word, moet veral die volgende punte benadruk word: die (literêre) kunswerk is outonoom; die voorverstaan van die werklikheid is 'n voorwaarde vir literêre outonomie; literêre outonomie is 'n voorwaarde vir appropriasie; die mimetiese boog is ' $n$ spiraal wat voortdurend in tyd en begrip vorentoe beweeg; en die herkonstruksie van die mimetiese boog is ' $n$ (hermeneutiese) taak wat self spiraalagtig is.

Sonder die literêrheid van letterkunde (inhoudelik en vormlik) is daar nie letterkunde nie. Ricoeur (1990b:173) beklemtoon dat "die verwagtingshorison eie aan letterkunde nie saamval met die alledaagse lewe nie", juis omdat die literêrheid van narratiewe fiksie 'n we- 
senlike nie-ooreenkomstigheid tussen alledaagse en artistieke taalgebruik konstitueer. Hierdie eerste afstand tussen letterkunde en die maatskaplik-politieke werklikheid verduidelik waarom die (goeie) betrokke literêre werk steeds as noodwendig-literêre en nie as politieke traktaat, preek of filosofiese besinning kan/moet verskyn nie. Ricoeur sit ook self in 'n kort passasie in die derde volume van Temps et récit sy siening oor betrokke literatuur, of die "sosiale invloed van die kunswerk", duidelik uiteen:

We can see the fruitfulness of these theses with respect to the old problem of the social influence of the work of art. We must challenge with equal force the thesis of a narrow structuralism which forbids 'moving outside the text' and that of a dogmatic Marxism which merely shifts onto the social place the worn-out topos of imitation naturae. (Ricoeur, 1990b:173.)

Alhoewel Ricoeur dus nie die probleem van betrokkenheid direk hanteer nie, is daar meer as genoeg rede om te aanvaar dat hy nóg estetiese outonomie, nóg estetiese heteronomie vooropstel. Trouens, hy beskou outonomie en heteronomie as deel van 'n geheel die sogenaamde mimetiese boog. Die drievoudige mimetiese proses dien juis as voorwaarde vir die literêre werk wat 'n verhoogde impak op die maatskaplik-politieke werklikheid wil maak. Die interafhanklikheid van die drie oomblikke van mimesis (mimesis $_{1}$, mimesis ${ }_{2}$, mimesis $_{3}$ ) behels dat mimesis transformatief is. Die mimetiese boog

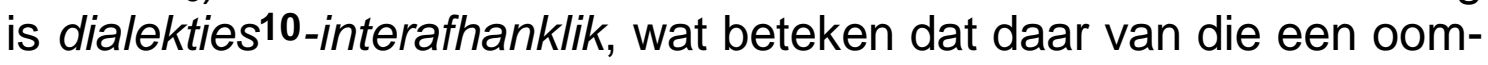
blik na die ander beweeg word op 'n wyse wat progressief en interbetreklik is. ${ }^{11}$ Aangesien die mimetiese boog nie gekonstitueer word deur lineêr-kousale relasies nie, maar deur só 'n dialektiek, vind daar bepaalde transformasies plaas wat altyd weer terugverwys na die boog in geheel. Ricoeur se transformerende idee van mimesis maak dit voorts vir hom moontlik om ook vormlike vernuwing te akkommodeer - iets wat nie geredelik met mimetiese teorieë geassosieer word nie.

10 Die woord dialektiek moet nie sonder meer gelykgestel word aan Hegel se gebruik daarvan nie. Ricoeur bedoel met dialektiek 'n proses van progessiewe interbetreklikheid, maar hierdie proses kulmineer nie vir hom in 'n Hegeliaanse Aufhebung van konsepte nie.

11 Vergelyk Johan Degenaar (1973) se opstel "Die verhouding tussen letterkunde en samelewing". Degenaar beskryf die verhouding tussen letterkunde en samelewing ook as dialekties, maar Ricoeur bied myns insiens 'n meer filosofies-uitgebreide idee van presies hoe sodanige verhouding lyk en werk. 
In 'n baie insiggewende voetnoot in Temps et récit, argumenteer Ricoeur dat die eerste afstand tussen kuns en werklikheid (die wesenlike nie-ooreenkomstigheid tussen alledaagse en literêre taalgebruik) verduidelik waarom 'n kunswerk ook deur middel van vormlike vernuwing invloedryk kan wees. Hy skryf:

This first distance explains why a work like Madame Bovary [by Flaubert] influenced customs more by its formal innovations (in particular by introducing a narrator who is the 'impartial' observer of his heroine) then did the openly moralizing interventions or denunciations so dear to socially committed writers. The absence of any answer to the moral dilemmas of an epoch is perhaps the most effective weapon available to literature to act on social customs and to change praxis ... Literature act only indirectly on social customs by creating what could be called second-order gaps in relation to the first-order gap between imaginary and everyday reality. (vgl. Ricoeur, 1990a: 319; kursivering - CK.)

Wanneer Ricoeur (1990b:179) die leeshandeling wat deel is van mimesis $_{3}$ (herkonfigurasie) bespreek, benadruk hy weereens dat daar 'n dialektiese verhouding tussen die eiesoortige referensiële vermoë en die meedeelbaarheid (communicability) van die letterkunde bestaan, asook dat hierdie verhouding 'n dialektiek tussen lees as stasis en lees as impetus veronderstel.

Reading appears by turns as an interruption in the course of action and as a new impetus to action [...] This fragile union can be expressed in the following paradox: the more readers become unreal in their reading, the more profound and farreaching will be the work's influence on social reality. (Ricoeur, 1990b:180.)

Die transformasie waartoe kuns in staat is, word gevolglik ten diepste veronderstel en moontlik gemaak deur die brose verbintenisse wat die ganse mimetiese boog konstitueer.

\section{Antjie Krog as betrokke digter}

$\mathrm{Na}$ afloop van die bespreking van Ricoeur se mimesisteorie kan 'n mens die volgende voorlopige definisie van transformerende mimesis waag: transformerende mimesis is ' $n$ interafhanklike, drievoudige proses wat progressief interbetreklik, maar steeds "broos" is. In hierdie afdeling argumenteer ek dat 'n mens hierdie beginsel van transformerende mimesis in die poësie van Antjie Krog kan identifiseer. Krog het die Afrikaanse leserpubliek van jongs af bekoor met die 
eerlike stilistiek van haar kaalvoetgedigte, maar kon hulle ook ontstel met die polities-uitgesproke en eroties-suggestiewe aard van haar digkuns. Alhoewel sy dus as 'n eietydse volksdigter (Gouws, 1998:550) getipeer kan word, bevat hierdie etiket alreeds die kontroversiële aspekte van haar werk en haar skrywerskap. Die skooldogtergedig "My mooi land" - 'n gedig waarin Krog die ideaal van 'n nie-rassige Suid-Afrika vooropstel - bied miskien die mees gepaste wegspringplek vir 'n gesprek oor betrokkenheid in die Krog-oeuvre, juis omdat hierdie gedig soveel impak gehad het.12

\section{1 "Hoe skryf sy die blou?": voor skryf}

Die wyse waarop "My mooi land" hanteer word, sowel as die chronologiese plasing daarvan in Krog se semi-outobiografiese werk 'n Ander tongval (Krog, 2005), werp lig op die eiesoortige verbindings wat in Krog se werk bestaan tussen skrywerskap en betrokkenheid. Die skryf van "My mooi land" word hier binne die groter konteks geplaas van 'n ontwakende digterskap wat sigself grootliks met liefdesgedigte en die natuur bemoei. Die skryf van hierdie politieke gedig word as 'n terloopse gebeurtenis gehanteer en daardeur gestroop van 'n eksplisiete, doelbewuste politieke inslag en/of oogmerk. Dit word eerder aangebied as net nóg 'n gedig wat sy ontstaan te danke gehad het aan ' $n$ besondere tipe belewing van die werklikheid en 'n bepaalde getrouheid in die weergee daarvan. Die eerste konfigurasies van skrywerskap in 'n Ander tongval (2005) lê spesifiek klem op skryf - en veral dig - as 'n poging tot weergee-intaal of ver-taling van die werklikheid met die oog daarop om 'n tipe ruimte te skep. In die passasie wat oor die eerste gewaarwordings van digterskap handel, word dig as 'n begeerte beskryf om die werklikheid te kan omskryf, om die werklikheid om te sit in taal, om "verlange te vertaal" (Krog, 2005:36). Hierdie begeerte dui op 'n bepaalde bewustheid of bewuswording van die werklikheid wat anders is as jou sogenaamde alledaagse bewussyn. Wat spesifiek anders is, is 'n versterkte perseptuele en verdiepte affektiewe bewuswording van die werklikheid. Sodanige bewuswording maak die betekenisrykheid van mimesis ${ }_{1}$ duidelik: veelvuldige bevoegdhede word veronderstel deur die moontlikheid van 'n versterkte persep-

12 "My mooi land" het oorspronklik in Krog se matriekjaar in haar skooljaarblad verskyn. Die gedig het wyd reaksie ontlok. Sensasionele koerantdekking het daarop gevolg; die gevange ANC-leier Ahmed Kathrada het dit vanuit die tronk (asook by sy vrylating jare later) voorgelees en Krog se pa is deur die Broederbond ingeroep om te verduidelik waar sy dogter aan haar "verligte ideale" kom (Krog, 2005:144). 
tuele en verdiepte affektiewe bewuswording van die werklikheid. Om die werklikheid te kan vertaal, is dit immers noodsaaklik dat 'n voorafbegrip van die werklikheid aanwesig is, wat die digter in staat stel om bepaalde elemente uit die werklikheid uit te soek. Deur middel van haar bevoegdheid om strukturele, simboliese en temporele kentrekke in die werklikheid te eien, vind die digter in die werklikheid self 'n aanvanklike leesbaarheid wat ver-taling moontlik maak. In die Krog-oeuvre word hierdie aanvanklike leesbaarheid dikwels aan die gehoorsintuig verbind en aan die digter se vermoë om (meermale afwagtend) te kan luister. In die gedig "digter wordende" (Krog, 2000) word hierdie tipe luister, wat in Ricoeur se terme 'n bevoegdheid genoem kan word, op eksemplariese wyse verbeeld. Die skryfproses word in hierdie gedig ook nóú aan die liggaam self verbind - iets wat konstant in die Krog-oeuvre voorkom. Skryf is vervolgens 'n proses wat uit 'n (liggaamlike) noodwendigheid voortvloei; en Krog beskryf ook in 'n Ander tongval (Krog, 2005:112-113) die totstandkoming van die gedigte in haar eerste bundel in terme van liggaamlike prosesse: "Dis of alles in haar bymekaarkom. Elke oop senuweepunt smelt saam met haar potlood en haar hele wese vind haar balans ..." (Krog, 2005:112). Weereens kan "digter wordende" hier gelees word as 'n versinnebeelding van die wyse waarop die digter haar liggaam inspan om te kan luister:

om jouself meteens gekniel te vind

bo-oor die hoorbaar kloppende wand

van 'n woord - soekend na daardie presiese

moment wat 'n versreël volloop in klank

(Krog, 2000:65.)

Die begeerte om die werklikheid te ver-taal gaan egter ook gepaard met die bewustheid van 'n bepaalde problematiek: "Hoe skryf sy die blou? Hoe skryf sy die seun?" (Krog, 2005:36). Die versterkte perseptuele en verdiepte affektiewe bewuswordings wat skryf voorafgaan is immers geen waarborg dat die skryfproses suksesvol en/of sonder moeite en pyn sal afloop nie - die broosheid van die mimetiese proses word hier onderstreep. Die gedig "skryfode" (Krog, 2000) dien, in geheel, as 'n eksemplariese literêre versinnebeelding van die broosheid wat so diep met die skeppingsproses verweef is. Hierdie gedig verleen sigself ook aan interpretasies wat gebruikmaak van die antropoloog Victor Turner se idee dat daar 'n verband getrek kan word tussen die liminale 13 fase van pre-industriële oor-

13 Die term liminaal is afkomstig van die Latynse limen wat "drempel" beteken. Volgens Turner (1982:37) word die liminale fase van 'n oorgangsritueel 
gangsrituele, en na-industriële kulturele ekspressie (wat hy die "liminoïede" noem). Marlies Taljard interpreteer "skryfode" as 'n epiese gedig, waarin die sprekende-ek vrywillig 'n grens na die liminale sone oorsteek, om daar tot insigte te kom wat uiteindelik versoening kan bewerkstellig (Taljard, 2007a:204-218 \& 2007b). Hierdie tipe interpretasie beklemtoon die broosheid van die mimetiese proses, aangesien die skeppende arbeid wat verrig moet word om 'n gedig te kan skryf nooit maklik en/of pynloos is nie: "en die skryf, die neerskryf, vind plaas in selfgeveg" (Krog, 2000:66).

\section{2 "wanneer die betekenis van 'n woord swig": skryf}

Die uiteindelike vervulling van die begeerte is om die werklikheid te kan omsit in taal vergestalt as die gedig-op-papier. Hierdie vervulling (in Ricoeur se terme, mimesis ${ }_{2}$ ) word weereens in die Krog-oeuvre verbind aan die liggaam en veral aan die bevrydendende, lewegewende oomblik van asemhaling: "Om vir die eerste keer asem te haal" (Krog, 2005:36). Die beeld van dig-as-asemhaling druk die gedagte uit dat die letterkunde 'n integrale funksie het en nie net bykomend tot die lewe self is nie.

[T]he ancient indestructibility of poetry helps you to survive in places where water, hunger and a violent death are the biggest enemies ... You cannot breathe as deeply anywhere as in a poem. (Krog, 2004a.)

Die beeld van dig-as-asemhaling is ' $n$ besonder gepaste metafoor vir mimesis ${ }_{2}$ : dit verbeeld die wyse waarop skryf 'n aktiwiteit is wat dít wat buite is, inneem, op 'n manier verwerk en dit dan weer uitlaat. Hierdie is die mediërende funksie van mimesis ${ }_{2}$. Waar mimesis tradisioneel verbind word aan die metafoor van die spieël, is daar in Krog se digkuns 'n dinamiese aspek wat die statiese aspekte verbonde aan blote weer-spieëling deurbreek. Na afloop van die "worstelende selfgeveg" (uit "skryfode" - Krog, 2000:70) wat met die skryfhandeling gepaard gaan, kan die digter dus in 'n "uitgevegte taal" (Krog, 2000:70-73) haar stem vind; sodanige "oplossing" is werklik "a solution that is the poetic act itself" (Ricoeur, 1990:66). Die mediasie wat mimesis ${ }_{2}$ bewerkstellig, dra dus iets tot die werk-

gekenmerk deur 'n fisiese en simboliese verwydering van die subjek, en die aanwesigheid van 'n anti-struktuur waarin bekende elemente op 'n vervreemdende wyse aangebied word ten einde uiteindelike integrasie te bewerkstellig wanneer daar na 'n nuwe fase toe beweeg word. Vergelyk veral From ritual to theatre: the human seriousness of play (Turner, 1982). 
likheid by: dit is ' $n$ manier om deur middel van talige representasie 'n realiteit te weerspieël wat terselfdertyd ook geskep word:

It's as if you break through the mirror for a moment and touch the riddle. As if you're standing on the threshold of breath. As if you get oxygen out of cold trees and advance suddenly. (Krog, 2004a.)

Hier is dus 'n transformerende mimesis waarin teks en werklikheid aan mekaar deelneem op dieselfde wyse as wat die mens, deur asemhaling, deelneem aan sy omgewing. Hiervolgens vereis die poësie 'n ander vorm van beleef, 'n ander vorm van bewussyn wat Krog aan die tradisionele Afrika-begrip van die imbongi ("pryssanger") verbind en, waarby sy haarself insluit. Die imbongi is 'n tussenganger wat tussen die volksleiers en die algemene volk moet beweeg op ' $n$ manier wat nie altyd bewustelik of rasioneel is nie. Op dieselfde wyse is Krog van haar eerste bundel af al reeds ' $n$ tussenfiguur, die "vroedvrou van 'n volk" (uit "Dogter van Jefta", Krog, 2004b:9) of, in Ricoeur se terme, 'n bemiddelaar. Die broosheid van die mimetiese boog word hier tot uitdrukking gebring in die spanning wat sodanige posisie behels. As imbongi is Krog deeglik bewus van die spanning wat daar dikwels tussen die politieke en die estetiese sfere bestaan. Sy druk ook herhaaldelik in haar poësie 'n gevoel van verontregting uit teenoor die politieke sfeer. Die gedig "1995" (Krog, 1995:6-7) druk die sprekende-ek se houding teenoor die politiek soos volg uit:
ek sê vooruit
hard
ek staan vir niks
ek skaar my by nêrens
niemand kom my naby
almal lyk dieselfde
almal is mans almal
is nekke almal
peule van mag

(Krog, 1995:6.)

Die digter distansieer haarself hierdeur van die kollektief politieke ("ek skaar my by nêrens") wat daarin spesialiseer om sekere beginsels ("ek staan vir niks") na te jaag. Politiek blyk trouens in alle gevalle 'n magspel te wees waarin uitruilbare mans die hoofrolle vertolk. In Kleur kom nooit alleen nie (2000) word hierdie sentimente geëggo in die gedig "ai tog!": 
mens is niemand se Afrikaner nie mens praat niemand se taal nie mens is nie 'n moer iemand se meriete nie mens is drolwit en pisswart mens skyt graag op die manne wat werk by die nuwe barcounter van identities

(Krog, 2000:47.)

Die poësie is dus nie die kneg van die politiek nie; trouens, die brutaliteit van die politieke arena bring die kuns juis in gevaar. In "parool" vra die sprekende-ek gevolglik:

(op watter manier

beskerm ek hierdie vers teen die kras

agteloosheid van politisering? ...)

(Krog, 1989:35.)

Terselfdertyd is dit egter ook waar dat die digter haarself nie blind hou vir die politieke realiteit nie. Krog neem immers in die tagtigerjare aktief deel aan die politieke stryd teen apartheid en skryf ook heelwat betrokke poësie (Van der Waal, 2005:1). Tydens haar Van Wyk-gedenklesing in 2004 het Krog ook uitdruklik beklemtoon dat sy die rol van die digter in die samelewing baie sterk aan politieke betrokkenheid verbind. Die digter moet polities betrokke wees, nie net deur haar digwerk nie, maar ook deur die waarnemings wat sy maak oor die sosiale lewe in die breë (Van der Waal, 2005:3). In die volgende strofe van "parool" word daar gesê: "ek skaam my vir die digter" (Krog, 1989:35). Die vers wat "beskerm" moet word, is dus nie die afgesnyde vers wat "volhard as luukse" (Krog, 1989:35) of "prutsel" (Krog, 1989:38) is nie - dit is eerder die vers wat "vlytig elke hegemonie [ondersoek] / om te kan asemhaal asemhaal asemhaal” (Krog, 1989:38).

\section{3 "in die begenadigde woord": na skryf}

Die literêre werk wat nie "nutteloos of prutsel" is nie, is juis 'n werk wat slegs geaktualiseer kan word deur die leser (of aanhoorder). Hierdie aktualisering kan egter slegs geskied indien die literêre werk se verwysingskapasiteit en vermoë om te kommunikeer gesamentlik geaktualiseer word (Ricoeur, 1990a:78). Sodanige aktualisering intensiveer ons verhouding tot die werklikheid deur middel van 'n tweede-orde verwysing of iconic augmentation wat die wêreld op nuwe maniere beskryf of konfigureer. Lesers word, deur hulle opname in die wêreld van die teks, 'n nuwe manier van kyk na die werklikheid gegun. 
Mimesis ${ }_{3}$ kan dalk beter begryp word wanneer Krog se idee van die digter as ruimteskepper van nader bekyk word. Met die skep van 'n ruimte bedoel Krog dat die digter 'n oopmaakproses aan die gang sit, 'n oopskryf wat die akkommodering van die Ander beteken. Krog verbind die konsep van ubuntu hieraan:

gasvryheid [...] hoe en wat jy skryf oor diegene wat nie jou eie is nie, die een deur wie jy tot jouself kan kom en kan word dit wat jy werklik is (Krog aangehaal deur Van der Waal, 2005:4).

In die filosofie van ubuntu sien Krog die fondament van alle etiek, naamlik die vermoë om die ander te akkommodeer. Daarom dat die gedig "ai tog!" ook eindig met die volgende:

mens hoort by haar wat daagliks woordeloos nuwe wolle by die mat vleg

$$
\text { (Krog, 2000:47.) }
$$

Die oënskynlike politieke oogmerke van die digter blyk dus eerder 'n etiese gevoeligheid te wees as wat dit noodwendig die nastreef van suiwer politieke ideale behels. Hierdie etiese sensitiwiteit hoort tuis in die poësie omdat poësie 'n lewegewende proses is, 'n "asemhaling", waarin ruimte geskep kan word waarin ook die Ander kan asemhaal.

In die gedigsiklus "land van genade en verdriet" uit Kleur kom nooit alleen nie (Krog, 2000) word die oorbrugging wat deur taal moontlik is, uitgebeeld. Waar die ruimte tussen-in ("in dié land so bloeiende tussen ons") die landskap self, die ek en die ander van mekaar skei as gevolg van die wandade van die verlede, kan nou deur middel van 'n nuwe, medemenslike taal'n tuiste vir albei gevind word:

hoor! hoor die opwel van medemenslike taal in haar sagte weerlose skedel

(Krog, 2000:38.)

en

mag ek jou vashou my suster

in dié brose oopvou van 'n nuwe, enkele medewoord

(Krog, 2000:41.)

Uiteindelik is dit dan moontlik om die ruimte tussen die ek en die ander te oorbrug deur middel van hierdie talige aspek van bestaan. Op hierdie manier bring poësie 'n werklike verandering aan die werklikheid teweeg deur 'n ruimte vir behoort te skep. Die tipe verandering wat hier ter sprake is, is weereens 'n spesifiek trans- 
formerende verandering. Van der Waal (2005:14) wys daarop dat Krog die "socially transformative potential of word-art" in haar oeuvre demonstreer. Sy tipeer Krog se voorstelling van die letterkunde as 'n "transformerende konsepsie". Wat Stephan Meyer (2002:13) 'n tipe linguistic turn ten opsigte van politieke betrokkenheid noem, bewerkstellig Krog as 't ware deur middel van transformerende mimesis. Die poësie kan as 'n medium van intersubjektiewe erkenning 'n baie belangrike bydrae tot die transformasie van die begrip ubuntu lewer. In die taal van medemenslikheid kan elkeen simbolies behoort.

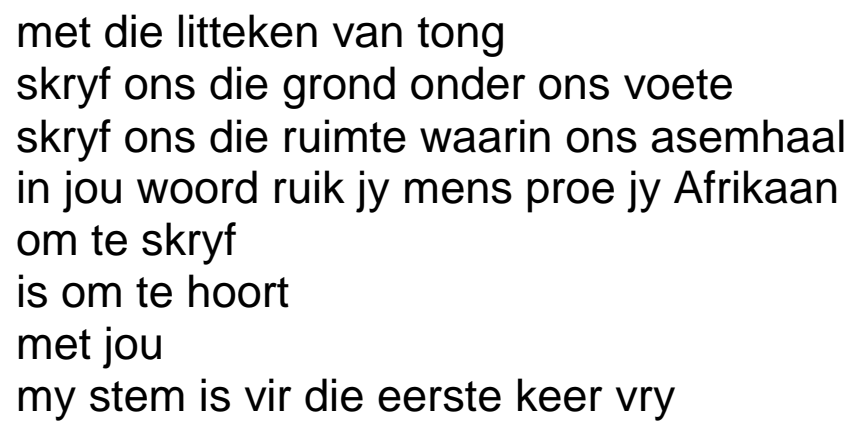

Hierdie talige transformasie of ruimteskepping is egter afhanklik van die brose verbintenis wat tussen die teks en haar lesers bestaan. Die behoort wat in en deur die "begenadigde woord" moontlik gemaak word, bly 'n moontlikheid wat toegesluit is in taaltekens indien dit nie deur die gedeelde verwysingsvermoë van mimesis ${ }_{3}$ deel word van die leser(s) se lewe nie. Die mimetiese boog is nie 'n kousale ketting nie, maar 'n interafhanklike, drievoudige proses wat progressief interbetreklik is. Die mimetiese toeëiening wat deur middel van die leeshandeling in die derde "oomblik" van die boog geskied, versterk en verdiep immers weer die perseptuele en affektiewe bewuswording van die werklikheid wat die eerste "oomblik" van die boog behels. Hierdie mimetiese terugbeweging is egter nie sirkelagtig nie, maar spiraalagtig: 'n mens se begrip en belewing van die werklikheid word nooit ten volle nie, maar tog progressief verdiep.

\section{Samevatting}

In haar "Defense of poetry", beskryf Krog die poësie as

... (a) fundamentally self-delighting inventiveness, something that takes pure pleasure in making use of language to catch something of the world (Krog, 2004a).

Dit is nie ten spyte van nie, maar juis omdat die poësie so 'n talige self-delighting inventiveness behels dat dit ook radikaal betrokke kan wees. Mimesis is uiteindelik ' $n$ voorwaarde vir betrokke letter- 
kunde wanneer 'n mens mimesis eerder as 'n transformerende proses, as 'n statiese weerspieëling beskou. In Krog se poësie is die vers outonoom, maar nie onafhanklik nie. Die voorverstaan van die werklikheid dien as voorwaarde vir hierdie outonomie; en die outonomie van poësie is die voorwaarde vir toeëiening. Die mimetiese boog is uiteindelik ' $n$ spiraal wat gedurig in tyd en begrip vorentoe beweeg, en die herkonstruksie van die boog is 'n taak wat self spiraalagtig is. Dit is ook die taak wat deur die letterkundige en/of estetikus opgeneem moet word. Vir die letterkundige behoort die moontlikheid van 'n verdere en meer grondige studie van die transformerende mimetiese beginsel in sowel Krog as in ander betrokke werke ondersoek te word. Die sentrale plek wat die liggaam in Krog se poësie inneem, behoort eweneens vir sowel die estetikus as diegene wat die filosofie van Ricoeur bestudeer, te wys op die kardinale rol van liggaamlikheid in mimetiese prosesse. Die betekenis van hierdie verbintenis behoort verder nagevors te word.

\section{Geraadpleegde bronne}

ABRAMS, M.H. 1953. The mirror and the lamp. New York: Oxford University Press.

ADORNO, T.W. 1977. Commitment. (In Jameson, F., ed. Aesthetics and politics. London: New Left Review.)

DANTO, A.C. 1997. After the end of art. Princeton: Princeton University Press.

DE LANGE, A.M. 1995. Writer, reader and representation; or, The theory and practice of commitment. (In Viljoen, H.M., red. Metodologie en representasie: metodologiese implikasies van enkele representasie opvattings vir die literatuurstudie. Pretoria: Raad vir Geesteswetenskaplike Navorsing. p. 293-337.)

DEGENAAR, J. 1973. Die verhouding tussen letterkunde en samelewing. (In Polley, J., red. Verslag van die simposium oor die Sestigers. Kaapstad: Human \& Rousseau. p. 152-160.)

DERRIDA, J. 1972. La dissémination. Paris: Éditions du Seuil.

EAGLETON, T. 1976. Marxism and literary criticism. London: Methuen.

GOODMAN, N. 1968. Languages of art. London: Oxford University Press.

GOUWS, T. 1998. Antjie Krog (1952- ). (In Van Coller, H.P., red. Perspektief \& profiel: 'n Afrikaanse literatuurgeskiedenis. Deel 1. Pretoria: Van Schaik. p. 550-563.)

HALLIWELL, S. 2002. The aesthetics of mimesis: ancient texts and modern problems. Princeton: Princeton University Press.

KROG, A. 1989. Lady Anne. Bramley: Taurus.

KROG, A. 1995. Gedigte 1989-1995. Groenkloof: Hond.

KROG, A. 2000. Kleur kom nooit alleen nie. Kaapstad: Kwêla Boeke.

KROG, A. 2004a. Defence of poetry. http://www.poetryinternational.org Datum van gebruik: 10 Apr. 2005.

KROG, A. 2004b. Eerste gedigte. Kaapstad: Human \& Rousseau.

KROG, A. 2005. 'n Ander tongval. Kaapstad: Tafelberg. 
LACOUE-LABARTHE, P. \& NANCY, J. 1989. The Nazi myth. Critical inquiry, 16(2):291-312.

MEYER, S. 2002. "The only truth stands skinned in sound": Antjie Krog as translator. Scrutiny2: Issues in English studies in South Africa, 7(2):3-19.

RANCIÈRE, J. 2006. The politics of aesthetics. London: Continuum.

RICOEUR, P. 1990a. Time and narrative. Vol. 1. Trans. from French by Kathleen McLaughlin \& David Pellauer. Chicago: The University of Chicago Press.

RICOEUR, P. 1990b. Time and narrative. Vol. 3. Trans. from French by Kathleen McLaughlin \& David Pellauer. Chicago: The University of Chicago Press.

RICOEUR, P. 1991. The function of fiction in shaping reality. (In Valdes, M.J., ed. A Ricoeur reader: reflection and imagination. Toronto: University of Toronto Press. p. 117-136.)

TALJARD, M.E. 2007a. Tussen Gariep en Neger: die representasie en konfigurasie van grense, liminaliteit en hibriditeit in Kleur kom nooit alleen nie van Antjie Krog. Potchefstroom: NWU. (D.Lit.-proefskrif.)

TALJARD, M.E. 2007b. Writing takes place in wrestling the self down: strategies of reconciliation in Kleur kom nooit alleen nie (Colour never comes on its own) by Antjie Krog. (In Viljoen, H.M. \& Van der Merwe, C.N., eds. Beyond the threshold: explorations of liminality in literature. New York: Peter Lang. p. 247-268.)

TURNER, V.W. 1982. From ritual to theater: the human seriousness of play. New York: PAJ Publications.

VAN DER WAAL, M. 2005. "Die uurwerk kantel": different conceptions of literature as contested terrain. http://irs.ub.rug.nl/ppn/277139627 Date of access: 3 Oct. 2005.

\section{Kernbegrippe:}

betrokkenheid

estetiese outonomie

mimesis

Ricoeur

Key concepts:

aesthetic autonomy

commitment

mimesis

Ricoeur 
